\title{
Coping with Agricultural Income Risks from Natural Disasters: Efficacy of Formal and Informal Mechanisms in Vulnerable Region of India
}

vinita kanwal ( $\sim$ vinitakanwal888@gmail.com )

Punjab Agricultural University https://orcid.org/0000-0002-5200-392X

Smita Sirohi

Embassy of India

\section{Research Article}

Keywords: arid India, income risks, risk coping mechanisms, natural disasters

Posted Date: February 10th, 2021

DOI: https://doi.org/10.21203/rs.3.rs-175072/v1

License: (c) (1) This work is licensed under a Creative Commons Attribution 4.0 International License.

Read Full License 


\section{Abstract}

Based on our analysis it can be concluded that the formal risk aversion mechanism has limited scope in the disaster-prone areas of the country. Addressing the assessment and adequacy of compensation amount along with information asymmetry in the formal insurance market should be a top priority for improving the efficacy. The ex-post measures under formal risk coping also have limited impact, indicating the underdevelopment of insurance and commercial credit markets in the region. Ex-ante risk aversion mechanism, particularly climate-resilient technologies may be conducive to the stable increase of farmers' income and the continuous development of rural economy in the long-run. Therefore, it is of great significance to provide farmers with assistance to address the income risk in better terms.

\section{Introduction}

Natural disasters embargo developmental progress as a consequence of economic losses incurred on humanity. Over the past decades, these losses are consistently escalating to a large scale. For instance, financial losses at the global scale were seven times high between 1992 and 2002, over the 1960s. Climate change is expected to augment the existing damage in the form of natural disasters in near future. The intensity of these natural disasters is expected to further increase due to prevailing climate change (Scott-Smith 2018; Cannon 2014; IPCC 2012; Khan and Khan, 2008). Natural disasters could be climate-induced and geophysical in nature. Climate induced natural disasters (CIND) include floods, droughts, extreme temperatures, storms and wildfires etc., while earthquakes, tsunamis and mass movements comprises geo-physically induced natural disasters.

Climate induced natural disasters (henceforth CIND) pose a real threat to the agriculture sector; although the damage caused by them has been largely under-reported (Lesk et al 2016; Diersen et al. 2002). Estimates suggest that in developing countries, the agriculture sector absorbs nearly 23 percent of the total losses caused by natural disasters. This damage stood almost 93 billion USD in crop and livestock production in between 2005 and 2014. Out of which more than $79 \%$ cumulative production losses are due to CIND. Among CIND, flood alone accounts for a large part of the damage $(37 \%)$ followed by drought (19\%) and other CIND (23\%) (FAO 2015; FAO 2013).

During the last decade between 2005 and 2015, CIND has inflicted substantial losses on crop and livestock production in developing countries. The losses were estimated to be higher than USD 10 billion per year in five out of ten study years. Lately in Africa, drought of Sahel and Horn region accounts for crop and livestock production losses of more than nine billion USD. The droughts in Latin America and the Caribbean island induced the losses, worth 6.5 billion USD in 2012 and 7.5 USD in 2014. Attributed to the series of monsoon floods and earthquakes, South Asia reported damage of ten billion USD in 2013. The floods that hit Pakistan in 2010 caused a loss of USD 4.5 billion. The consecutive three years droughts in Kenya since 2008 induced a loss of USD 1.5 billion (FAO 2015). Seasonal floods of India and Bangladesh induced an average annual loss worth more than 4 million tons in rice production 
(Mohantyet al 2013). The cyclone Gorky that hit Chittagong Division in Bangladesh in 1991 destroyed 0.13 million acres of cropland (BBS, 2011).

In developed nations also, CIND has severe financial implications in crop sector. The drought of 2002 in South Dakota induced a huge loss, worth more than 1.8 billion USD (Diersen and Taylor 2003) that was later revised to 1.4 billion USD (Diersen and Taylor 2003). The same drought in Missouri cost 251 million USD to the agriculture sector (Food and Agricultural Policy Research Institute 2003).

Given the scenario, recourse to formal and informal mechanisms is inevitable to address the uncertainties caused by CIND, irrespective of the level of economic development of a nation (Singh et al 2018; Shiferaw et al 2014; Yang 2010). Formal risk response mechanisms include prescribed system arrangements for risk management, particularly in terms of modern social security nets and commercial insurance. These mechanisms cover several dimensions such as the provision of economic resources, social capital formations, insurances against risks etc., Informal risk coping mechanisms on the other hand infers those risk aversion measures that include all approaches taken by farmers in the production process to avoid the risk. These measures usually include the adoption of climate resilient technologies, membership of the organization, making use of potent information, etc.

These formal or informal mechanisms could be ex-ante risk mitigation or ex-post risk management depending upon their time of applicability (Chepkoech et al 2020; Abid et al 2020; Williams et al 2019; Singh et al 2018; Jin et al 2016). Ex-ante risk management mechanism refers to risk prevention measures that farmers adopt in the course of production before the risk occurs in order to reduce income risk (Bardhan and Udry 1999; Fafchamps 1992; Morduch 1995). These are usually social security nets or crop insurance.

Conventionally in developing countries that are most vulnerable to CIND, the formal ex-ante risk management including crop insurance is a relatively new concept (Marichamy and Aananthi 2014; Clarke et al. 2012; Mosley and Krishnamurthy 1995). Low farm incomes regularly limit the affordability of these mechanisms and hence it calls for a strong driving force (Cole et al 2014; Matul et al. 2013; Hill and Robles 2011; Giné and Yang 2009). In absence of such force, perennial high losses incurred in the agricultural sector force commercially operated insurance companies to reduce their agricultural business. While High-income countries show a large range of ex-ante formal risk coping mechanisms, particularly agricultural insurance products that are mostly indemnity-based, benefitting from substantial government support; this is either absent in developing nations or at a nascent stage of evolution.

Lack of potential disaster damage realization, along with non-availability or non-satisfactory performance of ex-ante risk management mechanism it is inevitable to opt for ex-post risk coping options. On income losses, farmers generally rush to credit institutions to raise money for compensating financial losses. Moreover, the development of effective credit and insurance markets is likely to reduce economic inefficiencies and would turn into ideal risk management options (Yang 2010). Unfortunately; farmers face several constraints in their use which makes formal mechanisms functionally limited. Several underlying constraints and underdevelopment of this sector compels a farmer to adapt informal 
preventive measures to avoid the risk of either pre or post CIND occurrence (Thorat and Sirohi 2018; Kanwal 2018; Khan et al. 2010). These informal risk coping mechanisms include ex- ante risk reduction and ex-post risk coping mechanisms (Yang 2010; Shiferaw et al 2014). The ex-ante risk reduction mechanism refers to risk prevention measures that farmers adopt in the course of production before the risk occurs to smoothen up their income (Bardhan and Udry 1999; Fafchamps 1992; Morduch 1995). These are cataleptic preparations towards risk mitigations that include any conservative production techniques or methods to avoid future risk. On the other hand, ex-post strategies are the measures to which farmers opt post income risks, mainly to reduce the later effects (Abbas et al 2018; van Winsen et al 2016; Lekprichakul 2009). Individual farm household characteristics also have an important role in managing risk in time of income uncertainties. Thus, it is of great significance to understand the risk response measure taken by farmers and thereby adjudicating their efficacies.

In this context, this paper with its dual objectives aims to examine what role formal and informal risk response mechanisms play in easing income fluctuation? What methods do farmers prefer to avoid risks and the factors responsible for the choice of risk management mechanism? Being the most vulnerable state in terms of climate vagaries, Rajasthan was espoused for this study.

\section{Methodology}

\subsection{Model selection and estimation method}

A dichotomous logistic regression model is used to study the efficacy of formal and informal mechanisms in managing risk faced by farmers in the study area. A dichotomous variable representing 'no change' (0) and 'significantly lowered income' (1) in the event of any risk is used as the dependent variable.

The explanatory variables are mostly ordered categorical variables (qualitative). One method to deal with such variables is to change each multi-category qualitative variable into a number of dichotomous qualitative variables. However, data in this study is derived from the survey questionnaire and most of the explanatory variables are ordered categorical variables, in case they are changed in to several dichotomous qualitative variables, there will be too many final variables, which is not conducive to a clear explanation. Another method set out in the social science research studies to deal with ordered categorical variables is to give each option of variables a certain value and use the variables as continuous ones. The later mentioned approach is relatively simple and easy to explain, and hence is adopted in this study. However, this approach requires the assignment of independent variables to be the same as the actual size as much as possible, to avoid bias caused by improper assignment. As the questionnaire of this study is designed to classify the ordered categorical variables in detail, and attention has been paid to the distance set option to avoid improper assignment, this paper adopts the latter method for analysis. Assignment of specific variables is given in Table 1. Effect of formal and informal management options are also analyzed in reducing the income losses. The dependent variable 
is the degree of income fluctuation as farmers face the risk, that is, the change in the normal income caused by the risk factors. The model is given as:

\section{$\operatorname{Ln}\left(P_{i} / 1-P_{i}\right)=\propto_{o}+\propto_{1} X_{i}+\propto_{2} Y_{i}+\propto_{3} Z_{i}+\varepsilon_{i}$}

Where, $p_{i}$ indicates the probability of stable income, $1-p_{i}$ indicates the probability that income will be significantly lowered in the event of a risk, and $p_{i} / 1-p_{i}$ is the odds ratio of significantly reduced income. $a_{0}$ is a constant, $X_{i}$ denotes the set of formal risk management variables, $Y_{i}$ is the set of informal risk management variables, $Z_{i}$ indicates the household characteristics. $a_{1}, a_{2}$ and $a_{3}$ are respectively the sets of corresponding coefficients; $\varepsilon_{i}$ is a random error term.

\section{Data}

Western Rajasthan along with North-western is most prone to drought hazards with a frequency of at least one severe drought occurrence every four years (GoR 2018). The district of Bikaner was picked randomly. Its location is classified as $\mathrm{BW}_{\mathrm{h}}$ by Köppen and Geiger as there is virtually no rainfall during the year. The district is known for frequent droughts, fewer irrigation facilities, high dependence on monsoon, and persistent decline in productivity, and negative returns from the cultivation of traditional crops (Banerji and Upadhyay 1976; Bhuiyan et al. 2006). District categorized under the category of 'very high vulnerability' in the atlas of 'vulnerability of Indian agriculture to climate change' (Shinde and Modak, 2013).

The choice of 'flood-prone district' was based on the number of severe to moderate flood incidence in the past 30 years as obtained from various published sources (Kanwal et al. 2018; Wilk et al. 2018;Upadhyay 2014; Prasad et al. 2006). Accruing to the highest number of moderate and severe floods, the district of Kota was selected for this. The district is situated in the south-eastern part of Rajasthan (Fig. 1) and lies under humid and floods prone Agro-climatic zone. The selection of tehsils and villages in these districts was guided by the objective of capturing the extent of income loss in event of climate risk in the regions and the efficacy of different formal and informal risk response mechanisms. The study area comprises eighteen villages from both the districts.

For this study, a multi-stage sampling method was used. Complete enumeration of the households was carried out in 18 selected villages to gather information on landholding and herd size. In all, there were 4774 households among 18 sample villages (3159 in Bikaner district and 1615 in Kota district). A total of 180 households; 90 each from Bikaner and Kota were selected in probability proportion to the size of landholding and herd size (based on the details obtained in the complete enumeration) were studied in detail. One additional criterion for selecting these households was mandatory access and utilization of formal risk coping mechanisms. This is to draw inferences on dependence of households to informal risk response mechanisms even when it has access and availability of formal mechanisms. 
From these selected households, grass root information was gathered for the agriculture year 2018-19 by conventional survey method on a well-structured and pre-tested schedule through personal interview.

\section{Variable Selection}

The dependent variable is the degree of income fluctuation due to climatic shocks (in the form of drought and flood). The ideal method as emerged from literature for measuring income fluctuations is to study the change in the average annual income of farmers over the years (Yang 2010). However, in the Indian context, the data on farmers' income is not available on annual basis from secondary sources. Also, carrying out such primary surveys on annual basis is cumbersome, difficult and costs intensive. Taking this into account, the present study is designed to measure the income fluctuation of farmers with the subjective experience in enduring the income risk.

Information about to all the crops grown by sample farmers during three major seasons i.e. Kharif(rainy), Rabi (winter), and zaid (summer) was collected. The Cost incurred in various inputs, storage, marketing, and other agricultural operation were deducted from income realized by selling the product of these crops. The households' head was asked about the yield losses incurred in years of serious climatic risks (drought or floods). Based on this information, the fluctuation in their income was then calculated for both the periods i.e. during a normal year and during the year they faced a climatic risk. Given the Indian agricultural scenario, a loss of up to $15 \%$ of average annual income in normal year was considered as no significant loss (considering that farming is a risky enterprise) and is represented as 'unchanged (0)'.

Explanatory variables included in this research are studied under two major categories; a. formal risk management mechanisms and b. informal risk management mechanisms along with households' socioeconomic characteristics. Formal risk management mechanisms include ex-ante risk mitigation mechanisms and ex-post risk coping variables. Ex-ante risk mitigations are government lead preparations ahead of arising damages from unforeseen risks. The level of development of commercial insurance markets and difficulty in accessing government relief has been studied under this category Insurance coverage during and related aspects of Kisan Credit Card (KCC) are considered under this category.

KCC is an innovative short-term credit distribution system primarily formed to meet the input related credit requirements of the farmers since 1998 (Singh and Sekhon 2005; Bista et al 2012; Sharma et al 2013). The scheme has undergone several progressions over the subsequent period. Lately, all the credit loans taken under KCC are brought the under ambit of insurance to protect the interest of the farmer against loss of crop yield caused by natural calamities, pest attacks, etc. The amount of compensation received by farmers under KCC along with its adequacy against the total losses, as perceived by the farmers; are considered in the study. We also included the difficulty experienced in accessing this compensation to determine the efficacy of formal risk mitigation options.

Given widespread illiteracy and the absence of collateral, Indian farmers are largely deprived of utilizing government reliefs efficiently. These shortcomings of our food providers also stir up trouble for agencies providing government reliefs (including insurance companies). Here the staff behavior of these agencies 
in terms of interacting and educating these farmers is instrumental in accessing and utilizing the risk management instruments available for them. Also, if the average time taken in the preparation of documents is less, access to compensation becomes relatively easy for farmers. Furthermore, in an efficient functioning scenario, the release of the final compensation amount should not take much time. Correspondingly, the farmers must not be forced to make frequent visits to insurance agencies in an easy regime. Hence, based on cumulative scoring of aforesaid factors, the 'difficulty in obtaining compensation' rating was obtained. Based on this scoring we categorized the difficult experience into three categories (Table 1).

Ex-post risk coping variables are help reduce the aftereffect of damages due to risk. This category includes the amount of loan taken from formal institutions to smooth up daily consumption need, the scale of loan (measured by the number of agencies contacted for taking the loan), and difficulty in obtaining this loan (measured with the help of cumulative scores of bank staff behavior, the average time is taken in document preparation, total time taken in the release of loan amount and number of visits to banks). The variables reflect the degree of development of the formal credit market along with extent of inter-temporal consumption smoothening.

The second category of informal risk coping mechanism is further categorized into ex-ante risk reduction and ex-post risk coping mechanisms. Ex-ante risk reduction responses are unconscious preparations for risk minimizations. Variables, such as, membership of organization (that are helpful in technology sensitization among farm communities) along with access and adoptions of conservative production strategy are studied under this category.

Ex-post risk coping mechanisms indicate the degree of development of informal credit market. It is measured by the amount and scale of the informal credit (measured by the number of agency contacted for it). Risk pooling social networking has been subsumed under this variable. This category also includes the level of difficulty in the access to private loans which is measured with the help of cumulative scores of agency behavior; the average time is taken in document preparation, total time taken in the release of credit amount and number of visits to the agency. The agency usually contacted for informal credit in the study area includes friends, relatives, private moneylenders, and market traders.

Besides two major categories, farmers' demographic characteristics that include: social and economic variables are also included in the model. 'Social category' includes the age of household heads (average age of male and female heads of households), average years of schooling, and household size. On the other hand economic characteristics include average income level of the household, asset value of household (other than land), land size (in hectares), and number of cattle owned by the household. Further, an additional variable of location dummy was incorporated in the model to examine significant differences in the results of drought and flood-prone areas.

To eradicate the possibility of interactions among the explanatory variables, five different regression models are run. These models are developed under the constant control of family characteristics to understand the robustness of the results. First four models, namely model I, model II, model III, and model 
IV are worked by including variables of formal ex-ante risk mitigation, formal ex-post risk coping, informal ex-ante risk reduction and informal ex-post risk coping respectively along with family socio-economic characteristics. Model $\mathrm{V}$ was run by including all the explanatory variables (along with odd ratios). 
Explanation and assignment of variables

\section{Variable} category

\begin{tabular}{|c|c|c|}
\hline & \multicolumn{2}{|l|}{ explained variable } \\
\hline & dependent variable-income & $\begin{array}{l}\text { 0-basically unchanged, 1-significantly } \\
\text { lowered }\end{array}$ \\
\hline & \multicolumn{2}{|l|}{ explanatory variables } \\
\hline & \multicolumn{2}{|l|}{ formal mechanisms } \\
\hline \multirow{3}{*}{$\begin{array}{l}\text { ex-ante risk } \\
\text { mitigation }\end{array}$} & amount of compensation & in Indian rupees (₹) \\
\hline & adequacy of compensation & 0 -not adequate, 1 -adequate \\
\hline & difficulty in obtaining compensation & $\begin{array}{l}\text { 1-no access, } 2 \text { = moderately difficult, } 3 \text { - } \\
\text { easy }\end{array}$ \\
\hline \multirow{4}{*}{$\begin{array}{l}\text { ex-post risk } \\
\text { coping }\end{array}$} & amount of formal credit & in Indian rupees (₹) \\
\hline & scale of formal credit & $\begin{array}{l}\text { 1-none, 2-one or two, 3-two to four, } 4 \text { - } \\
\text { more than four }\end{array}$ \\
\hline & difficulty in obtaining formal credit & $\begin{array}{l}\text { 1-no access, } 2 \text { = moderately difficult, 3- } \\
\text { easy }\end{array}$ \\
\hline & \multicolumn{2}{|l|}{ informal mechanisms } \\
\hline \multirow{2}{*}{$\begin{array}{l}\text { ex-ante risk } \\
\text { reduction }\end{array}$} & membership of any organization & 0-no, 1-yes \\
\hline & $\begin{array}{l}\text { access and adoption of latest } \\
\text { agricultural technology }\end{array}$ & 0-no, 1-yes \\
\hline \multirow{4}{*}{$\begin{array}{l}\text { ex-post risk } \\
\text { coping }\end{array}$} & amount of informal credit & in Indian rupees (₹) \\
\hline & scale of informal credit & $\begin{array}{l}\text { 1-none, 2-one or two, 3-two to four, } 4 \text { - } \\
\text { more than four }\end{array}$ \\
\hline & difficulty in obtaining informal credit & $\begin{array}{l}1 \text {-no access } 2 \text { = moderately difficult, } 3 \text { - } \\
\text { easy }\end{array}$ \\
\hline & household characteristics & \\
\hline \multirow[t]{3}{*}{ Social } & age of the household head & in years \\
\hline & education & 0-illiterate, 1-literate \\
\hline & number of family members & In numbers \\
\hline
\end{tabular}




\begin{tabular}{|lll|}
\hline $\begin{array}{l}\text { Variable } \\
\text { category }\end{array}$ & variable explanation & Variable Assignment \\
\hline economic & average income level & $\begin{array}{l}\text { 1-below 1 lakh, 2 - 1 to 3 lakhs, 3- } \\
\text { more than 3lakh }\end{array}$ \\
\hline $\begin{array}{l}\text { asset value of household other than } \\
\text { land }\end{array}$ & in Indian rupees (₹) \\
& land size & In hectare (ha) \\
& number of cattle & In numbers \\
\hline other control variable & \\
\hline location dummy & 0-bikaner, 1-kota \\
\hline
\end{tabular}

\section{Results And Discussion}

\subsection{Details of formal risk response mechanism}

Details of formal risk response mechanisms have been studied under two major subheads. One is ex-ante risk mitigation and the other one is ex-post risk coping mechanisms.

A majority (63.9\%) of farmers experienced significant crop losses due to CIND (table 3). But nearly onefourth of them did not receive compensatory benefits under ex-ante risk mitigation strategies, despite bearing significant losses. Interestingly, the study indicates a labyrinth in the distribution of compensatory benefits when farmers accrue crop losses. For instance, more than one-third of farmers reported 'no losses' when climatic vagaries hit the region (table 2). Despite a significant number of these (26\%) got compensatory benefits. This disparity was more prevalent in flood-prone regions as compared to drought-prone region. Also, among the households experiencing significant losses, a significant fraction could not reap the benefits of compensatory payments. These results point forward the need of revamping the determination of compensatory payments.

Correspondingly, a considerable section of respondents (88.9\%) who received compensatory benefits indicated an inadequacy of compensation amount corresponding to the extent of losses. Largely, farmers experienced a high to moderate level of difficulty in access to compensation amount.

Table 2.

Distribution of households who received compensation across disaster affected regions (\% households) 


\begin{tabular}{|lll|}
\hline Extent of losses & $\begin{array}{l}\text { Basically unchanged } \\
(<10 \% \text { losses })\end{array}$ & Significantly lowered income $(>10 \%)$ \\
\hline Bikaner & 42.2 & 57.7 \\
& $(17)$ & $(83)$ \\
\hline Kota & 30.0 & 70.0 \\
& $(35)$ & $(65)$ \\
\hline Total & 36.2 & 63.8 \\
& $(26)$ & $(74)$ \\
\hline Note: Figures in parenthesis indicates \% of farm household that received compensation in the \\
respective loss category
\end{tabular}

More than $80 \%$ of respondents who received the compensatory benefits reported that the staff's behavior that provided compensation was very cordial. Regarding the documentation time, around three-fourth of the respondents stated that all the documents related to the compensation were finalized within a week. About $14.2 \%$ stated that it took a little over a week in the documentation related to compensation. Only a small segment (less than 3\%) reported a devotion of half of the year in preparation of compensatory documents.

Information on the time taken for the release of compensation was also obtained and a majority (67\%) reported that it took less than a week to the release of compensatory amount. Around $5.7 \%$ of households stated that compensating agency took less than 15 days and $22.6 \%$ stated that it took around one month for the same. Less than $5 \%$ reported a period of more than a month. Nearly half of the respondents reported that they have to visit the agency only once for release of the compensation amount while onefourth reported that they have visited the agency at least two times before the release of compensation.

Having a bank account is the most important factor in availing of compensatory benefits offered by the Government of India as compensatory benefits are transferred directly to the user's account linked with KCC. A majority (>97\%) of respondents in both the ecologies had bank accounts at least in any one of the nationalized banks (table 2). A few of the respondents possessed accounts in more than one bank as well. State Cooperative Banks (SCBs) turned out to be preferred in Bikaner while Regional Rural Banks (RRBs) were more popular in Kota.

Having a bank account is also important in accessing the loan post risk occurrences, in case a farmer has no crop insurance or if the insurance compensation is insufficient in comparison to the damages of risk. The average loan amount taken by a farmer from formal credit sources is ₹2, 65,072 annually, reflecting a high dependency on these. Formal credit sources comprised of KCC sponsored by scheduled commercial banks on which nearly $88.8 \%$ of households depend for credit requirements followed by village cooperative societies (39.4\%), and RRBs (18.4\%). Only a small section (5\%) reported a nondependence on any formal source for credit requirements. 
The popularity of formal institutions for credit was mainly due to discounted interest rates and relative ease in accessing loans. More than three-fourth respondents indicated cordial staff behavior along with negligible documentation time. Release of the loan amount was faster with larger wider choices of formal agencies. Hence, close to $90 \%$ respondents agreed that it is easy to obtain credit from formal institutions. 
Table 4

Descriptive statistics

\begin{tabular}{|c|c|c|}
\hline category & variable explanation & Variable description \\
\hline & \multicolumn{2}{|l|}{ explained variable } \\
\hline & dependent variable-income & $\begin{array}{l}\text { basically unchanged }-36.1 \% \text {, significantly } \\
\text { lowered }-63.9 \%\end{array}$ \\
\hline & \multicolumn{2}{|l|}{ explanatory variables } \\
\hline & \multicolumn{2}{|l|}{ formal mechanisms } \\
\hline \multirow{3}{*}{$\begin{array}{l}\text { ex- ante risk } \\
\text { mitigation }\end{array}$} & amount of compensation & $₹ 10,112$ \\
\hline & adequacy of compensation & not adequate $-88.9 \%$, adequate $-11.1 \%$ \\
\hline & $\begin{array}{l}\text { difficulty in obtaining } \\
\text { compensation }\end{array}$ & $\begin{array}{l}\text { no access }-42.8 \% \text {, moderately difficult }-53.3 \% \text {, } \\
\text { easy }-3.9 \%\end{array}$ \\
\hline \multirow{4}{*}{$\begin{array}{l}\text { ex-post risk } \\
\text { coping }\end{array}$} & amount of formal credit & ₹2,65,072 \\
\hline & scale of formal credit & $\begin{array}{l}\text { none }-5 \% \text {,one or two }-47.8 \% \text {, two to four - } \\
46.7 \% \text {, more than four }-0.6 \%\end{array}$ \\
\hline & $\begin{array}{l}\text { difficulty in obtaining formal } \\
\text { credit }\end{array}$ & $\begin{array}{l}\text { no access }-7.2 \% \text {, moderately difficult }-7.8 \% \text {, } \\
\text { easy }-85 \%\end{array}$ \\
\hline & informal mechanisms & \\
\hline \multirow{2}{*}{$\begin{array}{l}\text { ex- ante risk } \\
\text { reduction }\end{array}$} & membership of any organization & no- $61.7 \%$, yes-38.3\% \\
\hline & $\begin{array}{l}\text { access and adoption of latest } \\
\text { agricultural technology }\end{array}$ & no-74.4\%, yes- $25.6 \%$ \\
\hline \multirow{4}{*}{$\begin{array}{l}\text { ex-post risk } \\
\text { coping }\end{array}$} & amount of informal credit & ₹96,427 \\
\hline & scale of informal credit & $\begin{array}{l}\text { none }-41.1 \% \text {,one or two }-41.7 \% \text {, two to four - } \\
16.7 \% \text {, more than four }-0.6 \%\end{array}$ \\
\hline & $\begin{array}{l}\text { difficulty in obtaining informal } \\
\text { credit }\end{array}$ & $\begin{array}{l}\text { no access - 38.9\%moderately difficult- } 9.4 \% \text {, } \\
\text { easy- } 51.7 \%\end{array}$ \\
\hline & household characteristics & \\
\hline \multirow[t]{3}{*}{ Social } & age of the household head & 52 years \\
\hline & education & illiterate $-37.2 \%$,literate $-62.8 \%$ \\
\hline & number of family members & 6.23 \\
\hline economic & Income categories & $\begin{array}{l}\text { below } 1 \text { lakh }-84.4 \%, 1 \text { to } 3 \text { lakhs }-5.5 \% \text {, more } \\
\text { than 3lakh-10.1\% }\end{array}$ \\
\hline
\end{tabular}




\begin{tabular}{|c|c|c|}
\hline category & variable explanation & Variable description \\
\hline & $\begin{array}{l}\text { asset value of household other } \\
\text { than land }\end{array}$ & $₹ 6,95,000$ \\
\hline & land size & $3.15 \mathrm{ha}$ \\
\hline & number of cattle & 2.47 \\
\hline & \multicolumn{2}{|l|}{ other control variable } \\
\hline & location dummy & $0-50 \%, 1-50 \%$ \\
\hline
\end{tabular}

\subsubsection{Details of informal risk response mechanism}

A little more than one-third household has the membership of organization promoting technology sensitization among farm communities. These organizations included governance-related organizations (such as gram panchayats and gram sabha), farmers' cooperatives (including agricultural cooperative societies, dairy/milk cooperative societies, and credit cooperative society) and target-based organizations (Mahila mandal and rural youth club). Nearly one-forth respondents have access to the knowledge/ technologies disseminated by these institutions and have adopted them in the real world against the risk. These technologies include; using improved seed/varieties, changing crop plantation schedule, crop rotation, crop diversification, contract farming, etc.

In a scenario of underdeveloped credit and insurance markets, farmer generally resorts to informal sources for risk coping (Yang et al 2015). In our study area, informal sources of credit encompassed friends, relatives, merchants, and local money lenders. Relatives and friends were the most popular source of credit among informal agencies. The average loan amount taken by a farmer from informal credit sources is ₹96,427annually. This indicates that farmers in disaster-prone region of Rajasthan takes more amount from formal sources as compared to informal sources. The reasons for this high affinity towards formal sources are exceptionally high-interest rates and excessive collateral requirements of informal sources (merchants and moneylenders). Some farmers even indicated that asking for money from friends and relatives sacrifices the pride they have in society.

\subsubsection{Descriptive statistics of selected variables}

On average, household-heads are of 52 years age (Table 4) and close to two-thirds of them are formally literate (have a background of attending school at least at primary level). The average household size is six. Nearly $85 \%$ of farming households have an average annual income of less than one lakh; around $10 \%$ earn more than three lakhs and the rest fall somewhere in between. An average household possesses asset worth 6.9 lakh along with 3.15 hectare of landholding and two cattle.

\subsection{Implications of models}

We used STATA 15.0 software for ordered multinomial logistic regression analysis, and there are in total of 180 effective sample households included in regression models. Results from the measurement test 
are shown in Table 3. To understand the robustness of the results, variables of formal and informal risk response mechanisms are included respectively under the constant control of family characteristics with the degree of income losses as dependent variable. Under formal risk response, we include ex-ante risk mitigation and ex-post risk coping along with households' socio-economic characteristics. Results are represented in models I and II respectively. For informal risk response, variables of ex-ante risk reduction and ex-post risk coping are run separately in models III and IV respectively, along with households' socioeconomic characteristics. Finally, all the explanatory variables are included into the regression analysis process to obtain Model 5. To avoid the potential heteroscedasticity, the standard error in the table is the robust standard error, with the corresponding coefficient values.

\subsubsection{Effects of formal risk response mechanism}

Findings of the regression analysis show that the degree of development of the commercial insurance market makes an insignificant impact on income fluctuations. Thus, the ex-ante risk mitigation mechanism has a limited impact in the study area. Though, all the sample households had the access to these mechanisms; particularly due to compulsory insurance to loanee farmers, nearly $90 \%$ of them do not find the compensatory amounts to be adequate corresponding to the degree of losses. Also, the amount of compensation and ease in accessing compensatory benefits reduces the uncertainty from income losses but insignificantly. Further, the number of non-loanee farmers buying additional insurance is only around $2 \%$ of the total sample farmers. This could be attributed to the lack of incentives for insurance agencies to sell crop insurance to non-loanee farmers (Mukherjee and Pal 2017). This indicates that in case farmers respond to the income risk, the formal ex-ante risk mitigation mechanism goes a little way.

It is evident that globally farmers are reluctant in taking up crop insurance voluntarily even after subsidized premium rates due to several reasons (Cole et al 2014; Matul et al. 2013; Hill and Robles 2011; Giné and Yang 2009) and India is not an exception (Gaurav and Chaudhary 2020; Shirsath et al 2019). A few of these reasons include basis risk that is generally is not covered in an insurance product (Clarke 2016; Collier et al. 2009; Bateman and Piggott 2010), repeated contractual non-performance of schemes (Jensen et al. 2014; Doherty and Shlesinger 1990), and lack of basic understanding of the insurance product (Takahashi et al. 2016; Dercon et al. 2015). Thus, government intervention is indispensable in promoting insurance as a formal risk coping mechanism.

It is evident from the analysis that the amount of formal credit significantly reduces the income losses of farmers. The amount of formal credit has significant negative impacts on the income fluctuation in case farmers face the income risk; the odds ratio is 1 , which indicates that the change in the amount of formal credit will decrease the odds ratio of income fluctuations proportionately, but the absolute value of standardized regression coefficients very small (2.39e-06). Also, the ease in obtaining formal credit along with the reduced number of agencies contacted for the credit reduces the income fluctuations but these impacts are non-significant. This indicates that in the study areas of Rajasthan, the ex-post risk coping mechanisms have a limited role in alleviating income fluctuations. 
Also, the literature suggests that Indian rural credit markets suffer from many setbacks in their functioning. A few of these include unequal access to production and consumption credit between small and large farmers, diversion of productive loans to consumptive purposes, and credit rationing (Dreze et al., 1997).

\subsubsection{Effects of informal risk response mechanisms}

The ex-ante risk reduction mechanism in the study also included holding a cadre of any village organization. The regression results indicate that holding a cadre significantly decreases the risk of income losses. An increase in access and adoption of relevant agricultural technology is expected to decline the odd ratios of income loss. The results complement the expectations significantly. This implies that access to and adoption of all the technology necessarily reduces the income risk in the study area. In this context, the adoption of climate-resilient technologies is most important here. Thus, overall ex-ante risk coping mechanisms were found to have a good scope in the disaster-prone areas of Rajasthan.

The amount of informal credit has a significant and proportionate role in reducing income fluctuations; however the value of coefficients being relatively very small $(-7.10 \mathrm{e}-06)$. On the other hand, the scale of credit has a significant adverse impact on income fluctuations. This indicates that the more number of agencies contacted for smoothening the income fluctuations more is the loss. A major reason for this trend is an exorbitant rate of interest charged by private agencies in the study region ( 24 to $48 \%$ ). Despite this, farmers in rural areas generally resort to informal credit mainly because of two prominent reasons. First, the procedural simplicity of credit without any documentation and foremost, the convenience of time and form of loan repayment. Farmers in rural Rajasthan are allowed to repay the loan after harvesting, usually in the form of crop harvest. Moneylenders and middlemen usually purchase the standing crops and fulfill the repayment deeds after selling them at higher prices.

Reduced constraints of the informal credit market loans have a significant positive impact on farmers' income fluctuation; the odds ratio is 1.806 , indicating every one-level decrease on the constraints of informal loans will nearly double up the odds ratio of the income fluctuation. However, the absolute value of the standardized regression coefficient is 0.591 which means that the role of the constraints of the informal credit market is relatively more.

The overall result indicates that as against formal mechanisms informal risk response mechanisms have an overall significant impact in reducing risk arising of income fluctuations. This shows that the development of the informal lending market plays a negative role in fluctuations in the income of farmers. Two major reasons why the private credit market has a negative role than the formal credit market does are (1) exorbitantly high rate of interest for private agency push the farmers to a vicious cycle of poverty and (2) lack of availability of alternative credit provisions without collaterals make them extra dependent on these agencies.

Average family income level played a significant part in income fluctuation. The odds ratio is 1.240 , indicating that a rise in the income category of a family can proportionately decrease the odds ratio of 
income fluctuations. The absolute value of standardized regression coefficient is relatively large (0.473). We further found that the farmers' assets accumulation level though positive does not play any significant role in the income risk. Among other socio-economic characteristics, the age of household head had a significant impact in decreasing the odd ratio of income losses. An increase in the member, land size, and schooling of the head in the study area increases the odd ratio of income losses but insignificantly. Overall family characteristics variables have a limited scope in the study area in minimizing the risks of income losses. 
Table 5

Results of measurement test (model I-V)

\begin{tabular}{|c|c|c|c|c|c|c|}
\hline variable explanation & Model I & Model & Model III & $\begin{array}{l}\text { Model } \\
\text { IV }\end{array}$ & & Model V \\
\hline \multicolumn{7}{|l|}{ formal mechanisms } \\
\hline \multirow[t]{2}{*}{ amount of compensation } & $\begin{array}{l}-1.09 \mathrm{e}- \\
05\end{array}$ & & & & \multirow{2}{*}{$\begin{array}{l}1.000 \\
(1.310 \mathrm{E}- \\
05)\end{array}$} & $\begin{array}{l}-1.09 \mathrm{E}- \\
05\end{array}$ \\
\hline & $\begin{array}{l}(1.29 \mathrm{e} \\
05)\end{array}$ & & & & & $(1.3 \mathrm{E}-05)$ \\
\hline \multirow[t]{2}{*}{ adequacy of compensation } & 0.899 & & & & 2.186 & 0.781 \\
\hline & $(0.651)$ & & & & $(1.513)$ & $(0.692)$ \\
\hline difficulty in obtaining & 0.267 & & & & 1.166 & 0.153 \\
\hline compensation & $(0.343)$ & & & & $(0.531)$ & $(0.455)$ \\
\hline \multirow[t]{2}{*}{ amount of formal credit } & & $\begin{array}{l}-2.11 \mathrm{e}- \\
06^{\star \star \star}\end{array}$ & & & \multirow{2}{*}{$\begin{array}{l}1.000 * * * \\
(9.370 \mathrm{E}- \\
07)\end{array}$} & $\begin{array}{l}-2.39 \mathrm{e}- \\
06^{* \star \star}\end{array}$ \\
\hline & & $\begin{array}{l}(8.37 \mathrm{e}- \\
07)\end{array}$ & & & & $(9.4 \mathrm{E}-07)$ \\
\hline \multirow[t]{2}{*}{ scale of formal credit } & & 0.268 & & & 1.354 & 0.303 \\
\hline & & $(0.329)$ & & & $(0.627)$ & $(0.462)$ \\
\hline difficulty in obtaining & & 0.035 & & & 0.928 & -0.075 \\
\hline formal credit & & $(0.308)$ & & & $(0.319)$ & $(0.343)$ \\
\hline \multicolumn{7}{|l|}{ informal mechanisms } \\
\hline \multirow[t]{2}{*}{ membership } & & & $-1.282^{\star \star \star}$ & & $4.406^{\star \star \star}$ & $-1.482^{\star \star \star}$ \\
\hline & & & $(0.429)$ & & $(2.498)$ & $(0.567)$ \\
\hline \multirow{2}{*}{$\begin{array}{l}\text { Access and adoption of latest } \\
\text { agricultural technology }\end{array}$} & & & $-0.672^{\star}$ & & 0.568 & -0.566 \\
\hline & & & $(0.426)$ & & $(0.262)$ & $(0.461)$ \\
\hline \multirow[t]{2}{*}{ amount of informal credit } & & & & $\begin{array}{l}-7.40 \mathrm{e}- \\
06 \star \star \star\end{array}$ & $1.000 * \star \star$ & $\begin{array}{l}-7.10 \mathrm{e}- \\
06^{\star \star}\end{array}$ \\
\hline & & & & $\begin{array}{l}(2.53 e- \\
06)\end{array}$ & $06)^{-12}$ & $\begin{array}{l}(3.29 \mathrm{E}- \\
06)\end{array}$ \\
\hline \multirow[t]{2}{*}{ scale of informal credit } & & & & $0.997 * \star$ & $2.198^{\star \star}$ & $0.787 \star \star$ \\
\hline & & & & $(0.463)$ & $(1.178)$ & $(0.536)$ \\
\hline
\end{tabular}

$*, * *$ and $* * *$ indicate levels of significance at the statistical levels of $10 \%, 5 \%$ and $1 \%$ respectively 


\begin{tabular}{|c|c|c|c|c|c|c|}
\hline variable explanation & Model I & $\begin{array}{l}\text { Model } \\
\text { II }\end{array}$ & Model III & $\begin{array}{l}\text { Model } \\
\text { IV }\end{array}$ & & Model V \\
\hline difficulty in obtaining & & & & $0.528 * \star$ & $1.806^{\star \star}$ & $0.591^{\star \star}$ \\
\hline informal credit & & & & $(0.261)$ & $(0.563)$ & $(0.311)$ \\
\hline \multicolumn{7}{|l|}{ household characteristics } \\
\hline \multirow{2}{*}{ age of the household head } & $-0.023^{\star}$ & -0.021 & $-0.033^{\star \star}$ & $-0.022^{\star}$ & $0.980^{*}$ & -0.020 \\
\hline & $(0.013)$ & $(0.014)$ & $(0.015)$ & $(0.014)$ & $(0.015)$ & $(0.015)$ \\
\hline \multirow[t]{2}{*}{ education } & 0.321 & 0.350 & 0.287 & 0.383 & 1.691 & 0.525 \\
\hline & $(0.384)$ & $(0.395)$ & $(0.387)$ & $(0.411)$ & $(0.731)$ & $(0.432)$ \\
\hline \multirow[t]{2}{*}{ number of family members } & 0.061 & 0.049 & 0.129 & 0.111 & 1.088 & 0.083 \\
\hline & $(0.086)$ & $(0.087)$ & $(0.096)$ & $(0.093)$ & $(0.114)$ & $(0.105)$ \\
\hline \multirow[t]{2}{*}{ land size } & 0.108 & $0.143^{\star}$ & 0.078 & $0.178^{\star \star}$ & $1.000 * \star$ & $0.215^{\star \star}$ \\
\hline & $(0.085)$ & $(0.088)$ & $(0.089)$ & $(0.089)$ & $\begin{array}{l}(3.720 \mathrm{E}- \\
07)\end{array}$ & $(0.097)$ \\
\hline \multirow[t]{2}{*}{ Income categories } & $-0.605^{\star}$ & $-0.593^{\star}$ & $-0.661^{\star \star}$ & -0.402 & 1.240 & -0.473 \\
\hline & $(0.320)$ & $(0.327)$ & $(0.317)$ & $(0.378)$ & $(0.121)$ & $(0.388)$ \\
\hline \multirow[t]{2}{*}{ asset value of household } & $\begin{array}{l}1.63 e- \\
07\end{array}$ & $\begin{array}{l}1.52 \mathrm{e}- \\
07\end{array}$ & \multirow{2}{*}{$\begin{array}{l}1.76 e-07 \\
(3.3 e-07)\end{array}$} & \multirow{2}{*}{$\begin{array}{l}-2.06 \mathrm{e}- \\
07 \\
(3.33 \mathrm{e}- \\
07)\end{array}$} & \multirow{2}{*}{$\begin{array}{l}0.623 \\
(0.242)\end{array}$} & \multirow{2}{*}{$\begin{array}{l}5.82 \mathrm{e}-08 \\
(3.72 \mathrm{e}- \\
07)\end{array}$} \\
\hline & $\begin{array}{l}\left(3.31 e^{-}\right. \\
07)\end{array}$ & $\begin{array}{l}\left(3.12 e^{-}\right. \\
07)\end{array}$ & & & & \\
\hline \multirow[t]{2}{*}{ number of cattle } & -0.026 & \multirow{2}{*}{$\begin{array}{l}-6.3 e- \\
04 \\
(0.070)\end{array}$} & -0.036 & 0.159 & 1.038 & 0.037 \\
\hline & $(0.059)$ & & $(0.057)$ & $(0.0672)$ & $(0.073)$ & $(0.070)$ \\
\hline \multirow[t]{2}{*}{ location dummy } & $0.736 *$ & 0.433 & 0.010 & $0.917 * \star$ & 1.151 & 0.141 \\
\hline & $(0.415)$ & $(0.406)$ & $(0.432)$ & $(0.443)$ & $(0.816)$ & $(0.708)$ \\
\hline \multirow[t]{2}{*}{ constants } & 1.116 & 1.299 & $1.969 * \star$ & -0.191 & - & 0.154 \\
\hline & $(0.908)$ & $(1.038)$ & $(0.947)$ & $(1.016)$ & & $(1.234)$ \\
\hline log pseudo-likelihood & -110.09 & -108.86 & -106.51 & -99.76 & -91.71 & -90.11 \\
\hline Wald chi square & $14.88^{*}$ & $18.30 * \star$ & $21.91^{\star \star \star}$ & $25.62^{\star \star \star}$ & $41.92^{\star \star \star}$ & $41.92^{\star \star \star}$ \\
\hline Pseudo R2 & 0.064 & 0.075 & 0.095 & 0.152 & 0.221 & 0.221 \\
\hline
\end{tabular}

Robust standard errors are given in parenthesis 


\section{Conclusion And Policy Suggestions}

Farmers resort to multiple formal and informal options to avoid the income risk that includes ex-post and ex-ante risk response measures. Based on our analysis it can be concluded that the formal risk aversion mechanism has limited scope in the disaster-prone areas of the country. Addressing the assessment and adequacy of compensation amount along with information asymmetry in the formal insurance market should be a top priority for improving the efficacy. The ex-post measures under formal risk coping also have limited impact, indicating the underdevelopment of insurance and commercial credit markets in the region.

Against the background of the lack of formal risk response mechanism and that these mechanisms are functionally limited; the farmers have to rely on the informal risk response mechanism to deal with the income risk. Ex-ante risk aversion mechanism, particularly climate-resilient technologies may be conducive to the stable increase of their income and the continuous development of rural economy in the long-run. Therefore, it is of great significance to provide farmers with assistance to address the income risk in better terms. Because informal credit institutions plays important role in the region for risk reduction, it is important to consider the policies that check on exorbitant interest rates charged by some of these informal credit institutions.

It is also advised that macro-level policy toward better social protection should be designed and implemented considering the equity parameter of the households. It is further important that the government should take up alternative savings or insurance-based schemes for rural households to reduce the starvation, sale of assets, and borrowings to manage the impact of sudden shocks including climate-related. The development of the credit market, government safety nets, and skill development for jobs and income-earning activities should be the prime imperative of government. Finally, social protection policies should be targeted for selected households keeping in view their social and economic status and borrowing from formal or informal sources.

As far as risk coping mechanisms are concerned, it is advisable to constantly increase the social capital for farmers and reduce the frangibility of farmers to meet the market economy to strengthen their ability to cope with the risk of income fluctuations. Improving rural financial services, reducing constraints for farmer credits, enhancing the ability of farmers to handle the income risk through ex-post measures would be of great help. Improving the standard of the rural social security and helping the poor farmers in the maintenance of living standards as well as providing the enterprises that are engaged in rural insurance service with subsidies granted for policy considerations can induce the efficacy of risk management option.

$<$

\section{Declarations}




\section{Funding-}

Authors acknowledge the funding support of Indian Council of social science research

\section{References}

1. Abid M, Ali A, Raza M, Mehdi M (2020) Ex-ante and ex-post coping strategies for climatic shocks and adaptation determinants in rural Malawi. Climate Risk Management, 27, p.100200.

2. Auffhammer M, Schlenker W (2014) Empirical studies on agricultural impacts and adaptation. Energy Economics, 46, pp.555-561.

3. Banerji R, Upadhyay D (1976) A survey of drought and scarcity in Rajasthan. Proc Indian Acad Sci 42(1):15-21.http://ir.amu.ac.in/6090/1/DS\%202324.pdf

4. Bardhan P, Udry C (1999) Risk and insurance in an agricultural economy. Development Economics, pp.94-109.

5. Abbas A, Amjath-Babu TS, Kächele H, Usman M, lqbal MA, Arshad M, Shahid MA, Müller K (2018) Sustainable survival under climatic extremes: linking flood risk mitigation and coping with flood damages in rural Pakistan. Environmental Science and Pollution Research, 25(32), pp.3249132505.https://doi.org/10.1007/s11356-018-3203-8

6. Abid M, Ali A, Raza M, Mehdi M (2020) Ex-ante and ex-post coping strategies for climatic shocks and adaptation determinants in rural Malawi. Climate Risk Management, 27, p.100200.

7. Auffhammer M, Schlenker W (2014) Empirical studies on agricultural impacts and adaptation. Energy Economics, 46, pp.555-561.

8. Banerji R, Upadhyay D (1976) A survey of drought and scarcity in Rajasthan. Proc Indian Acad Sci 42(1):15-21.http://ir.amu.ac.in/6090/1/DS\%202324.pdf

9. Bardhan P, Udry C (1999) Risk and insurance in an agricultural economy. Development Economics, pp.94-109.

10. Bateman, $\mathrm{H}_{\text {.., }}$ and Piggott, J., (2010). Too much risk to insure? The Australian (non-) market for annuities. https://repository.upenn.edu/cgi/viewcontent.cgi?article=1204\&context=prc_papers

11. Bhuiyan C, Singh RP, Kogan FN (2006) Monitoring drought dynamics in the Aravalli region (India) using different indices based on ground and remote sensing data. Int J Appl Earth ObsGeoinf 8(4):289-302 https://doi.org/10.1016/j.jag.2006.03.002

12. Bista DR, Kumar P, Mathur VC (2012) Progress and performance of Kisan Credit Card Scheme with a case study of Bihar. Agricultural economics research review, 25(347-2016-16912), pp.125-135.

13. Cannon T (2014) World disasters report 2014-focus on culture and risk. https://www.ifrc.org/worlddisasters-report-2014

14. Chepkoech W, Mungai NW, Stöber S, Lotze-Campen H (2020) Understanding adaptive capacity of smallholder African indigenous vegetable farmers to climate change in Kenya. Climate Risk Management, 27, p.100204. 
15. Clarke DJ (2016) A theory of rational demand for index insurance. American Economic Journal: Microeconomics, 8(1), pp.283-306.

16. Clarke DJ, Mahul O, Rao KN, Verma N (2012) Weather based crop insurance in India. The World Bank.

17. Cole S, Stein D, Tobacman J (2014) Dynamics of demand for index insurance: Evidence from a longrun field experiment. American Economic Review, 104(5), pp. 284-90.

https://doi.org/10.1257/aer.104.5.284

18. Collier B, Skees J, Barnett B (2009) Weather index insurance and climate change: opportunities and challenges in lower income countries. The Geneva Papers on Risk and Insurance-Issues and Practice, 34(3), pp.401-424.https://doi.org/10.1057/gpp.2009.11

19. Deaton A (1989). Saving in developing countries: Theory and review. The World Bank Economic Review, 3(suppl_1), pp.61-96. https://doi.org/10.1093/wber/3.suppl_1.61

20. Dercon S, Gunning, JW, Zeitlin A (2015) The demand for insurance under limited trust: Evidence from a field experiment in Kenya. Development Economics.Dercon, S., Gunning, J., and Zeitlin, A. (2011). The demand for insurance under limited credibility: evidence from kenya. International Development Conference. DIAL.https://cdep.sipa.columbia.edu/sites/default/files/cdep/DGZ_201703.pdf

21. Diersen M, Taylor G (2003) Examining economic impact and recovery in South Dakota from the 2002 drought.https://openprairie.sdstate.edu/cgi/viewcontent.cgi?article=1172\&context=econ_staffpaper

22. Diersen MA, Taylor G, May A (2002) Direct and indirect effects of drought on South Dakota's economy.https://openprairie.sdstate.edu/cgi/viewcontent.cgi? referer=https://scholar.google.co.in/\&httpsredir=1\&article=1422\&context=econ_comm

23. Doherty NA, Schlesinger H (1991) Rational insurance purchasing: Consideration of contract nonperformance. In Managing the Insolvency Risk of Insurance Companies (pp. 283-294). Springer, Dordrecht. https://doi.org/10.1007/978-94-011-3878-9_11

24. Drèze J, Lanjouw P, Sharma N (1997) Credit in Rural India: A Case Study.|| LSE STICERD Development Economics Research Paper 6. London: Development Economics Research Programme, Suntory and Toyota International Centres for Economics and Related Disciplines.

25. Fafchamps M (1992) Cash crop production, food price volatility, and rural market integration in the third world. American journal of agricultural economics, 74(1), pp.90-99.

26. FAO (2010) Livelihoods strategies and household resilience to food insecurity: An empirical analysis to Kenya. http://erd.eui.eu/media/BackgroundPapers/Alinovi-RomanoD'Errico-Mane.pdf

27. FAO (2013a) Resilient livelihoods- disaster risk reduction for food and nutrition security framework programme. http://www.fao.org/3/a-i3270e.pdf

28. FAO (2013b) Disaster risk Reduction: Strengthening livelihood resilience. http://www.fao. org/docrep/018/i3325e/i3325e15.pdf

29. FAO (2015) The impact of natural hazards and disasters on agriculture and food security and nutrition. http://www.fao.org/3/a-i4434e.pdf 
30. Gaurav S, Chaudhary V (2020) Do farmers care about basis risk? Evidence from a field experiment in India. Climate Risk Management, 27, p.100201.

31. Giné X, Yang D (2009) Insurance, credit, and technology adoption: Field experimental evidence from Malawi. Journal of development Economics, 89(1), pp.1-

11.https://doi.org/10.1016/j.jdeveco.2008.09.007

32. Government of Rajasthan, State Agriculture Plan (SAP) and State Agriculture Infrastructure Development Plan Development Plan (SAIDP) under RKVY-RAFTAAR: 14th Financial Commission (2017-18 to 2019-20). ,

33. Hill RV, Robles M (2011) Flexible insurance for heterogeneous farmers: Results from a small-scale pilot in Ethiopia. Internat. Food Policy Research Inst.

34. IPCC (2007) Climate change 2007: synthesis report. Contribution of working groups I, II and III to the fourth assessment report of the intergovernmental panel on climate change, pp.95-212.

35. IPCC (2012) Managing the risks of extreme events and disasters to advance climate change adaptation: a special report of working groups I and II of the Intergovernmental Panel on Climate Change. Cambridge University Press, Cambridge (UK).

36. Jensen N, Barrett C (2017). Agricultural index insurance for development. Applied Economic Perspectives and Policy, 39(2), pp.199-219. https://doi.org/10.1093/aepp/ppw022

37. Jin J, Wang W, Wang X (2016) Adapting agriculture to the drought hazard in rural China: household strategies and determinants. Natural Hazards, 82(3), pp.1609-1619.

38. Kanwal V (2018) Analysis of risk and vulnerability of rural farm households to natural disasters in Rajasthan. Doctoral thesis, National Dairy Research Institute (NDRI), Karnal, India

39. Kanwal V, Pandey D, Kumar S (2018) A comparative analysis of crop diversification between flood and drought prone areas of Rajasthan. Indian J Econ and Dev 14(1a):168-174. https://doi.org/10.5958/2322-0430.2018.00053.7

40. Kanwal V, Sirohi, S, Chand P (2020). Effect of drought on livestock enterprise: Evidence from Rajasthan. Indian Journal of Animal Sciences, 90(1), pp.94-98.

41. Khan H, Khan A (2008) Natural hazards and disaster management in Pakistan. Available at https://mpra.ub.uni-muenchen.de/11052/1/MPRA_paper_11052.pdf

42. Khan ME, Hazra A, Bhatnagar I (2010) Impact of Janani Suraksha Yojana on selected family health behaviors in rural Uttar Pradesh. J Fam Welfare 56(9):9-

22.https://pdfs.semanticscholar.org/6aed/b2ce03817490f1ee40efa2f172ed8993a0ee.pdf

43. Kochar A (1999). Smoothing consumption by smoothing income: hours-of-work responses to idiosyncratic agricultural shocks in rural India. Review of Economics and Statistics, 81(1), pp.5061.https://doi.org/10.1162/003465399767923818

44. Lekprichakul T (2009) Ex ante and ex post risk coping strategies: How do subsistence farmers in southern and eastern province of Zambia cope?. Research Institute for Humanity and Nature, Kyoto, Japan.https://www.chikyu.ac.jp/resilience/files/ReportFY2008/ResilienceProject_Report2009_16.pdf 
45. Lesk C, Rowhani P, Ramankutty N (2016) Influence of extreme weather disasters on global crop production. Nature, 529(7584), pp.84-87.https://doi.org/10.1038/nature16467

46. Marichamy K, Aananthi N (2014). kisan credit card-a boon to small farmers in India. Tactful Management Research Journal, 2(8), pp.1-6.

47. Matul M, Dalal A, De Bock O, Gelade W (2013) Why people do not buy micro insurance and what we can do about it. Microinsurance Paper, (20).

48. Mohanty S, Wassmann R, Nelson A, Moya P, Jagadish SVK (2013) Rice and climate change: significance for food security and vulnerability. International Rice Research Institute, 14, pp.1-14. https://assets.publishing.service.gov.uk/media/57a08a4440f0b652dd00064c/DPS49_content.pdf

49. Morduch, J (1995). Income smoothing and consumption smoothing. Journal of economic perspectives, 9(3), pp.103-114. https://doi.org/10.1257/jep.9.3.103

50. Mosley P, Krishnamurthy R (1995) Can crop insurance work? The case of India. The Journal of Development Studies, 31(3), pp.428-450. https://doi.org/10.1080/00220389508422371

51. Mukherjee S, Pal P (2017) Impediments to the spread of crop insurance in India. Economic and Political Weekly, 52(35), pp.16-19.

52. Prasad AK, Kumar KV, Singh S, Singh RP (2006). Potentiality of multi-sensor satellite data in mapping flood hazard. Journal of the Indian society of remote sensing, 34(3), p.219. https://doi.org/10.1007/BF02990651

53. Scott-Smith T (2018) Paradoxes of resilience: A review of the World Disasters Report 2016. Development and Change, 49(2).

54. Sharma A, Choudhary S, Swarnakar VK (2013) A study on impact of Kisan Credit Card scheme among the beneficiary farmers in Sehore district of Madhya Pradesh. International Journal Of Science And Research, 2(1), p.154157.

55. Shiferaw B, Tesfaye K, Kassie M, Abate T, Prasanna BM, Menkir A (2014) Managing vulnerability to drought and enhancing livelihood resilience in sub-Saharan Africa: Technological, institutional and policy options. Weather and Climate Extremes, 3, pp.67-79.

56. Shinde SS, Modak P (2013) Vulnerability of Indian agriculture to climate change.

57. Shirsath P, Vyas S, Aggarwal P, Rao KN (2019) Designing weather index insurance of crops for the increased satisfaction of farmers, industry and the government. Climate Risk Management, 25, p.100189.

58. Singh C, Rahman A, Srinivas A, Bazaz A (2018) Risks and responses in rural India: Implications for local climate change adaptation action. Climate Risk Management, 21, pp.5268.https://doi.org/10.1016/j.crm.2018.06.001

59. Singh H, Sekhon MK (2005) Cash-in benefits of the Kisan Credit Card Scheme: onus is upon the farmer. Indian Journal of Agricultural Economics, 60(902-2016-67443).

60. Singh NP, Anand B,Khan MA (2018) Micro-level perception to climate change and adaptation issues: A prelude to mainstreaming climate adaptation into developmental landscape in India. Natural 
Hazards, 92(3), pp.1287-1304.

61. Takahashi K, Ikegami M, Sheahan M, Barrett, CB (2016). Experimental evidence on the drivers of index-based livestock insurance demand in southern ethiopiaEthiopia. World Development, 78:324340. https://doi.org/10.1016/j.worlddev.2015.10.039

62. The climate change double whammy: Flood damage and the determinants of flood insurance coverage, the case of post-Katrina New Orleans. Climate Risk Management, 27, p.100210.

63. Thorat VS, Sirohi S (2018) Income risk and management strategies of rural households: evidence from distressed regions of Maharashtra. Agric Econ Res Rev, 31(347-2018-5151):101-111. https://doi.org/10.5958/0974-0279.2018.00026.5

64. Upadhyaya $\mathrm{H}$ (2014) Vulnerability and adaptation to climate change in the context of water resource with reference to Rajasthan (PhD Thesis). Jaipur (India): The IIS University.

65. van Winsen F, de Mey Y, Lauwers L, Van Passel, S, Vancauteren M, Wauters E (2016) Determinants of risk behaviour: effects of perceived risks and risk attitude on farmer's adoption of risk management strategies. Journal of Risk Research, 19(1), pp.56-78.

https://doi.org/10.1080/13669877.2014.940597

66. Wilk J, Jonsson AC, Rydhagen B, Rani A, Kumar, A (2018) The perspectives of the urban poor in climate vulnerability assessments-The case of Kota, India. Urban climate, 24, pp.633-642. https://doi.org/10.1016/j.uclim.2017.08.004

67. Williams PA, Crespo O, Abu M (2019) Adapting to changing climate through improving adaptive capacity at the local level-The case of small holder horticultural producers in Ghana. Climate Risk Management, 23, pp.124-135.

68. Yang WANG (2010). Income uncertainty, risk coping mechanism and farmer production \& management decision: an empirical study from Sichuan Province. Agriculture and Agricultural Science Procedia, 1, pp.230-240.https://doi.org/10.1016/j.aaspro.2010.09.029

69. Yang X, Liu Y, Bai W, Liu B (2015) Evaluation of the crop insurance management for soybean risk of natural disasters in Jilin Province, China. Natural Hazards, 76(1), pp.587-599.

\section{Figures}



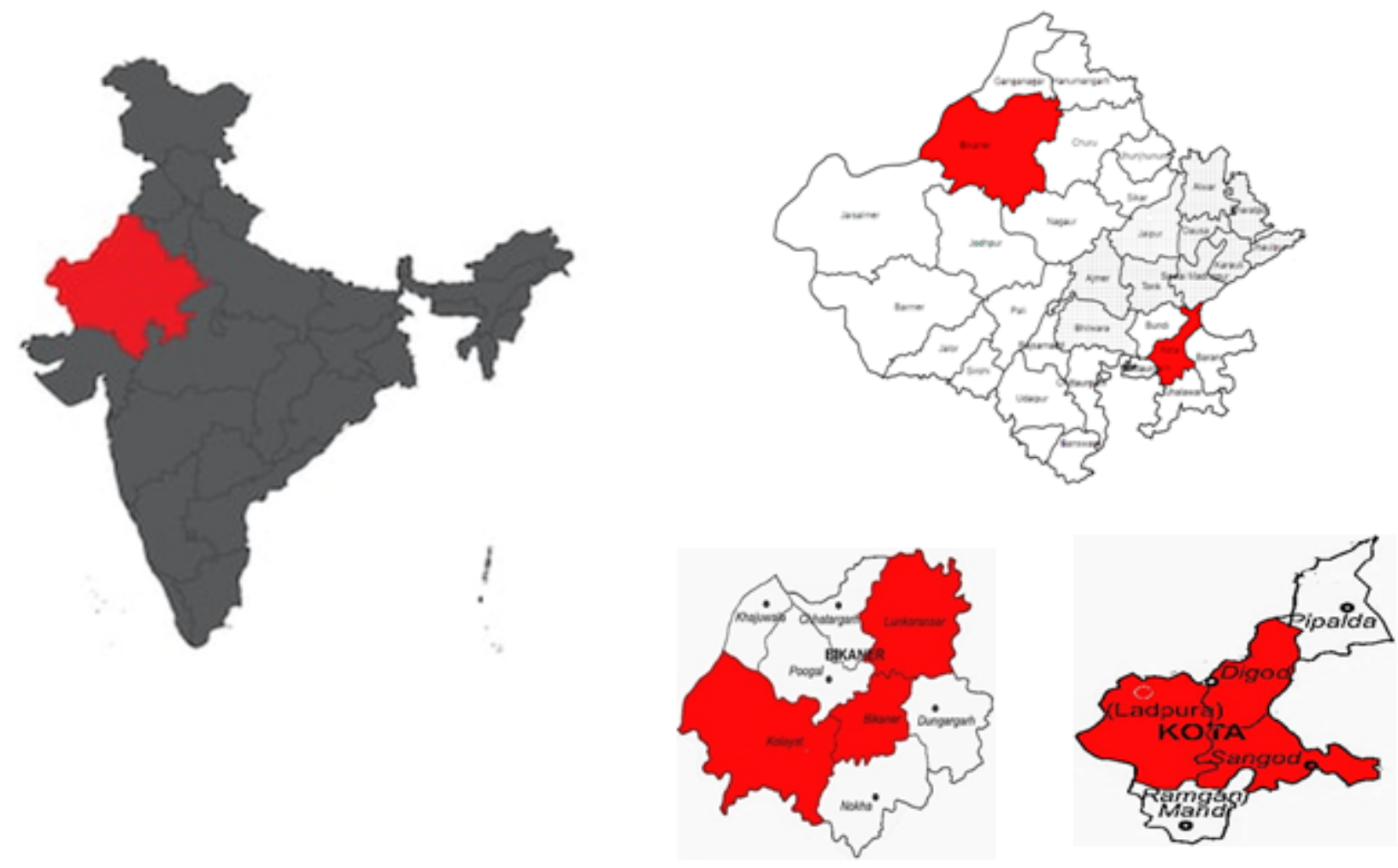

\section{Figure 1}

Location map of drought and flood-prone regions, Rajasthan Note: The designations employed and the presentation of the material on this map do not imply the expression of any opinion whatsoever on the part of Research Square concerning the legal status of any country, territory, city or area or of its authorities, or concerning the delimitation of its frontiers or boundaries. This map has been provided by the authors. 